Agro-Science Journal of Tropical Agriculture, Food, Environment and Extension Volume 9 Number 3 September 2010 pp. 161-169

ISSN 1119-7455

\title{
CROP RESIDUES AND AGRO-INDUSTRIAL BY-PRODUCTS USED IN TRADITIONAL SHEEP AND GOAT PRODUCTION IN RURAL COMMUNITIES OF MARKUDI LGA
}

\author{
Onyeonagu, C.C. and Njoku, O.L. \\ Department of Crop Science University of Nigeria, Nsukka, Nigeria
}

\begin{abstract}
A study of crop residues and agro-industrial by-products in Makurdi was conducted in June, 2008. Interview schedule was administered to farmers in five communities in Makurdi Local Government Area of Benue State, Nigeria. Fourteen (14) crop residues and eleven (11) agro-industrial byproducts were identified. The crop residues were grouped under cereal crop residues (3), root crop residues (5), legume crop residues (3), and fruit crop residues (3). All the sampled respondents kept livestock and depend on the natural pasture as the main source of feed for their animals. The mean stock number per farmer in this study was 14.0 for goats and 10.2 for sheep with the highest numbers being in the Agan community. Crop residues collection in this area is done twice daily. The source of crop residues in the area is generally close to the farmers' residence being 400 metres away. Most of these crop residues are available and utilized all the year round and are fairly palatable to ruminant animal with a mean score of 2.0. Palatable and very palatable crop residues (with mean scores of 3.0 and 4.0, respectively), constitute 56.0\%, while unpalatable materials constitute only $8.0 \%$ of all the residues. Most of the crop residues have low levels of anti nutrients and are therefore suitable for livestock feeding.
\end{abstract}

Key word: Crop residues, agro-industrial by-products, livestock, anti nutrients.

\section{INTRODUCTION}

With the take off of the agro-industrial revolution in Nigeria, many agricultural and industrial by-products were produced in such quantities that they constituted a problem of waste disposal (Tegbe, 1981). In the late 1960's and early 1970's, local demand for agroindustrial by-products like groundnut cake, cotton seed cake and palm kernel cakes could not absorb the available quantities. This prompted Fetuga and Ogunfowora (1976) to advocate the exportation of these commodities. These by-products have nevertheless, over the years, gained a lot of recognition in livestock feeding.

Agricultural by-products such as cassava peels, cocoa husks, maize cobs, and wheat offals among others are now widely used as animal feed. The trend has changed from the situation in which these by-products were considered as waste and are now being converted to animal protein for human consumption. Gone also are the days when industrial by-products such as brewers spent grains from the brewing industries, wheat and maize offals from the flour industries and molasses from the sugar industries were considered as pollutants and therefore burnt. (Iyeghe-Erakpotobor et al., 2002). Integration of livestock and crop residue allow resources to be recycled more effectively in livestock production enterprise. Large quantities of crop residues produced on private and government farms in Nigeria are wasted year after year. Some are left to rot in the field, which may improve soil fertility anyway, but most are burned. There is evidence that livestock fed with crop residues and agro-industrial by-products could achieve substantial weight gains (O'Donovah, 1979).

The abundant supply of crop residues and agro-industrial by-products at reasonable prices could enhance production and reduce cost of compounded feeds while not adversely affecting the performance of the animals. Because of increases in human population and consequent high cost and demand for conventional feedstuffs such as groundnut cake and soyabean meal, it has become increasingly necessary that alternative feed ingredients be found to reduce the competition between, man and livestock (Iyeghe-Erakpotobor et al., 2002). A major limiting factor in the use of these 
products is the presence of certain antinutritional factors that militate against their utilization (Adegbola and Omole, 1973).

Recently there has been growing policy recognition of the role of non-conventional feed resources in livestock production (FAO, 1999). All ruminants depend on two major feed resources. These are crop residues and agroindustrial by-products and they play a significant role in the nutrition of ruminant animals (Agarwal and Verma, 1983).

There is very little information on the actual availability and usage of crop residues and agro-industrial by-products in the eastern part of Nigeria compared to the northern part.

The knowledge of the availability and utilization of crop residues and agro-industrial by-products in the agro-ecological zones of Nigeria is important for assessing the potential of those resources. In spite of the increasing importance of crop residues, there is paucity of information on the crop residues available in Benue State. Accordingly, research was undertaken within the area to:

1. identify the crop residues and agroindustrial by-products in use in the traditional animal rearing systems in Markudi rural communities.

2. determine the seasonality of availability, preference rating, uses, ease of availability and distribution of identified crop residues and agroindustrial by-products in the area.

3. estimate animal numbers among farmers and identify the constraints/problems encountered by livestock farmers in crop residue and agro-industrial by-products utilization in Markudi rural areas.

4. evaluate the anti-nutrient factors in the identified crop residues and agroindustrial by-products.

\section{MATERIALS AND METHODS}

The study was conducted in five communities in Makurdi Local Government Area of Benue State. A semi structured interview schedule and field visits were used in this study. Five communities (Agan, Yaikyo, Adaka, Akile, Wurukum) in Makurdi LGA were selected for the study. A total of 40 farmers (8 farmers per community) were randomly selected and interviewed.

The information required in the interview schedule included:

(i) The types of crop residues

(ii) Perceived animal acceptability and palatability of crop residue

(iii) Distribution of crop residues

(iv) Availability and frequency of collection of crop residues

(v) Seasonality of crop residues

(vi) Availability rating of crop residues was based on mean scores to the nearest whole number (Key: $1=$ scarce; 2 = moderately available; and 3 = easily available)

(vii) Frequency of collection is the ratio of the total number of collections per community to the number of farmers per community.

The interview schedule further typified the respondents in terms of

(a) age, sex and name

(b) livestock holding per farmer

(c) problems encountered in crop residue collection.

Chemical analysis:

The crop residues were dried in an air tight oven, at $80^{\circ} \mathrm{C}$, and milled into ground form. The anti-nutrients analysed included: tannin, phytate, alkaloid and saponin. The method described by Price and Butter (1997) was used to determine the tannin content of the sample. The method described by Rachel (1979) was used to determine phytate. The alkaloid and saponin contents of the samples were determined according to the methods described by Berley (1969).

Statistics analysis: The data from the chemical evaluation were analysed using the method outlined for completely randomized design (CRD) with 3 replications. Means were subsequently separated using the standard error of the difference between two means (s.e.d.) according to Steel and Torrie (1980). The data from the interview schedule were analysed using means and percentages as described by Steel and Torrie (1980). 


\section{RESULTS}

The mean livestock holding per farmer ranged from 2 to 40 goats and 2 to 50 sheep per farmer in the study area (Table 1). The highest mean livestock holding was obtained in Agan community with a mean of 30.13 (mainly small stock) and 1.6:1 for goat: sheep ratio.

Ninety eight percent $(98 \%)$ of the farmers were between 21 and 50 years old and therefore sufficiently experienced to give reliable data (Table 2). Also all the sample respondents kept livestock and have the natural pasture as the main source of feed for their livestock.

The study identified fourteen (14) crop residues which were grouped into: cereal crops, root crops, fruits crops, and leguminous crops. Eleven agro-industrial by-products were also identified in the study area (Table 3). The most frequently used crop residues (i.e. those with mean usage $\geq 15 \%$ ) across all the sampled communities include: maize offal, yam peel and cassava peels.

Wheat bran, millet Stover, cocoyam peel, potatoes peel, potatoes vine, cotton seedcake, beniseed cake, castor seed cake, groundnut haulms, cowpea haulms, brewers dry grain, molasses, Brewers spent grain, palm kernel cake, banana peel, plantain peel are not common in the five communities (Table 4).

Mean score of frequency of collection of crop residues and agro-industrial by-products in five communities in Makurdi L. G. A. indicated that majority of the farmers feed their livestock twice daily (Table 5). The distance from source of collection of crop residues for most farmers are very close (Table 6).

Most of the crop residues and agroindustrial by-products are available and utilized all the year round (Table 7). Residues from root crops are available all the year round, while those from the fruit crops are more available during the dry season.

Table 8 summarized the perceived animal acceptability rating of crop residues. Generally, most crop residues are fairly palatable with a mean score of 2.0 based on the rating scale. Palatable and very palatable residues (with mean score of 3.0 and 4.0 , respectively) constitute $56.0 \%$ while unpalatable constitute only $8.0 \%$ of all residues. Cereal crop had greater number of crop residues.

Table 1: Summary of livestock holding per farmer per community in Markudi local government area

\begin{tabular}{|c|c|c|c|c|c|c|c|c|c|}
\hline \multirow[b]{2}{*}{ Community sampled } & \multicolumn{9}{|c|}{ Number of farmers sampled } \\
\hline & \multicolumn{9}{|c|}{ GOAT } \\
\hline Agan & 7 & 4 & 40 & 30 & 20 & 16 & 6 & 25 & 18.50 \\
\hline Yaikyo & 4 & 24 & 5 & 2 & 20 & 10 & 33 & 13 & 13.75 \\
\hline Adaka & 6 & 5 & 10 & 18 & 2 & 21 & 5 & 5 & 9.00 \\
\hline Akile & 20 & 30 & 20 & 3 & 4 & 5 & 32 & 14 & 16.00 \\
\hline Wurukum & 11 & 4 & 7 & 24 & 4 & 20 & 25 & 7 & 12.75 \\
\hline Mean & \multicolumn{9}{|c|}{ SHEEP } \\
\hline Agan & 6 & 6 & 21 & - & 5 & 7 & - & 50 & 11.88 \\
\hline Yaikyo & 3 & 16 & 4 & 4 & - & 7 & 2 & 7 & 5.38 \\
\hline Adaka & 4 & 6 & 6 & 12 & 3 & 10 & 2 & 3 & 5.75 \\
\hline Akile & 27 & 50 & 22 & 4 & 3 & 7 & 23 & 12 & 18.5 \\
\hline Wurukum & - & 3 & 5 & 18 & 2 & 32 & 10 & 6 & 9.5 \\
\hline Mean & 8 & 16.2 & 11.6 & 7.6 & 2.6 & 12.6 & 7.4 & 15.6 & 10.2 \\
\hline \multicolumn{10}{|c|}{ GOAT AND SHEEP } \\
\hline Agan & 13 & 10 & 61 & 30 & 25 & 21 & 6 & 75 & 30.13 \\
\hline Yaikyo & 7 & 40 & 9 & 6 & 20 & 13 & 34 & 20 & 18.63 \\
\hline Adaka & 10 & 11 & 16 & 30 & 5 & 31 & 7 & 8 & 14.75 \\
\hline Akile & 47 & 80 & 42 & 7 & 7 & 12 & 55 & 26 & 34.50 \\
\hline Wurukum & 11 & 10 & 12 & 43 & 6 & 52 & 35 & 13 & 22.75 \\
\hline Mean & 17.6 & 30.2 & 28.0 & 23.2 & 12.6 & 25.8 & 27.4 & 28.4 & 24.15 \\
\hline & \multicolumn{9}{|c|}{ GOAT: SHEEP RATIO } \\
\hline Agan & $1.2: 1$ & $1: 1.5$ & $1.9: 1$ & - & $4: 1$ & $2: 1$ & - & $1: 2$ & $1.6: 1$ \\
\hline Yaikyo & $1.3: 1$ & $1.5: 1$ & $1: 25: 1$ & $2: 1$ & - & $1.4: 1$ & $16: 1$ & $1.9: 1$ & 2.6:1 \\
\hline Adaka & $1.5: 1$ & $1: 1.2$ & $1.6: 1$ & $1.5: 1$ & $1.5: 1$ & $2.1: 1$ & $2.5: 1$ & $1.6: 1$ & $1.6: 1$ \\
\hline Akile & $1: 1.7$ & $1: 1.7$ & $1: 1.1$ & $1.3: 1$ & $1.3: 1$ & $1: 1.4$ & $1.4: 1$ & $1.2: 1$ & $1: 1.2$ \\
\hline Wurukum & - & $1.3: 1$ & $1.4: 1$ & $1.3: 1$ & $2: 1$ & $1.6: 1$ & $2.5: 1$ & $1.2: 1$ & $1.3: 1$ \\
\hline Mean & $1.2: 1$ & $1.2: 1$ & $1.4: 1$ & $2: 1$ & $3.8: 1$ & $1.1: 1$ & $2.7: 1$ & $1: 2$ & $1.4: 1$ \\
\hline
\end{tabular}


Traditional Sheep and Goat Production in Rural Communities of Markudi LGA

Table 2: Age, gender, number of children, status and type of pasture in Makurdi local government area.

\begin{tabular}{|c|c|c|}
\hline Farmers' characteristics & Number of respondents & $\%$ of respondents \\
\hline \multicolumn{3}{|l|}{ Age } \\
\hline$<20 \mathrm{yrs}$ & 0 & 0 \\
\hline $21-50 y r s$ & 39 & 98 \\
\hline $51-80 y r s$ & 1 & 2 \\
\hline$>80 \mathrm{yrs}$ & 0 & 0 \\
\hline \multicolumn{3}{|l|}{ Sex } \\
\hline male & 33 & 82.5 \\
\hline female & 7 & 17.5 \\
\hline \multicolumn{3}{|l|}{ Marital status } \\
\hline married & 27 & 67.5 \\
\hline single & 13 & 32.5 \\
\hline \multicolumn{3}{|l|}{ No. of children } \\
\hline none & 0 & 0 \\
\hline $1-4$ & 14 & 58.85 \\
\hline $5-10$ & 12 & 46.15 \\
\hline$>10$ & 0 & 0 \\
\hline \multicolumn{3}{|l|}{ Type of pasture } \\
\hline natural & 40 & 100 \\
\hline sown & 0 & 0 \\
\hline pure & 0 & 0 \\
\hline mixed & 0 & 0 \\
\hline
\end{tabular}

Table 3: Distribution of crop residues and agro-industrial by-products (\% of respondents)

\begin{tabular}{|c|c|c|c|c|c|c|}
\hline S/No & Residues & Agan & Wurukum & Akile & Adaka & Yaikyo \\
\hline \multicolumn{7}{|c|}{ Cereal crop residues } \\
\hline 1 & Millet Stover & - & - & - & 2.5 & 2.5 \\
\hline 2 & Rice husk & 7.5 & 12.5 & 5 & 2.5 & 7.5 \\
\hline 3 & Rice straw & 5 & 5 & 2.5 & - & - \\
\hline \multicolumn{7}{|c|}{ Root crop residues } \\
\hline 4 & Yam peel & 12.5 & 10 & 17.5 & 17.5 & 17.5 \\
\hline 5 & Cassava peel & 20 & 15 & 17.5 & 20 & 20 \\
\hline 6 & Cocoayam peel & 2.5 & - & - & 2.5 & - \\
\hline 7 & Potatoes peel & 2.5 & 5 & - & 2.5 & - \\
\hline 8 & Potatoes vine & 2.5 & 2.5 & 2.5 & 2.5 & 2.5 \\
\hline \multicolumn{7}{|c|}{ Fruits crop residues } \\
\hline 9 & Banana peel & 10 & 2.5 & 5 & 7.5 & 10 \\
\hline 10 & Plantain peel & 5 & 5 & 2.5 & 2.5 & 2.5 \\
\hline 11 & Orange peel & 5 & 5 & 5 & 5 & 5 \\
\hline \multicolumn{7}{|c|}{ Leguminous crop residues } \\
\hline 12 & Groundnut haulms & - & - & - & - & 2.5 \\
\hline 13 & Cowpea haulms & - & - & - & - & - \\
\hline 14 & Soyabean haulms & 17.5 & 10 & 15 & 12.5 & 10 \\
\hline \multicolumn{7}{|c|}{ Agro- industrial by-products } \\
\hline 15 & Groundnut cake & 17.5 & 15 & 2.5 & 7.5 & 2.5 \\
\hline 16 & Cotton seed cake & - & - & - & - & 5 \\
\hline 17 & Beniseed cake & 2.5 & 2.5 & - & - & 2.5 \\
\hline 18 & Castor seed cake & 5 & - & 2.5 & 2.5 & - \\
\hline 19 & Palm kernel cake & 2.5 & 5 & 5 & 7.5 & 2.5 \\
\hline 20 & Brewers dry grain & 10 & 5 & 5 & - & - \\
\hline 21 & Molasses & 2.5 & 2.5 & 7.5 & 5 & 2.5 \\
\hline 22 & Brewers spent grain & 5 & 2.5 & 10 & 2.5 & 2.5 \\
\hline 23 & Rice bran & 15 & 10 & 15 & 12.5 & 10 \\
\hline 24 & Maize offal & 12.5 & 17.5 & 15 & 17.5 & 12.5 \\
\hline 25 & Wheat bran & - & - & - & - & 5 \\
\hline
\end{tabular}


Onyeonagu, C.C. and Njoku, O.L.

Table 4: Mean scores of the availability of crop residues and agro-industrial byproducts in sampled communities of Makurdi Local Government Area (to the nearest whole number)

\begin{tabular}{|c|c|c|c|c|c|c|c|}
\hline S/No & Residues & Agan & Wurukum & Akile & Adaka & Yaikyo & Mean \\
\hline & Cereal crop residues & & & & & & \\
\hline 1 & Millet Stover & - & - & - & - & 1 & 0.0 \\
\hline 2 & Rice husk & 1 & 1 & 1 & - & 1 & 1.0 \\
\hline \multirow[t]{2}{*}{3} & Rice straw & 2 & 2 & 1 & 2 & 1 & 1.6 \\
\hline & Root crop residues & & & & & & \\
\hline 4 & Yam peel & 2 & 2 & 3 & 3 & 3 & 3.0 \\
\hline 5 & Cassava peel & 3 & 2 & 3 & 3 & 3 & 3.0 \\
\hline 6 & Cocoayam peel & 1 & - & - & 1 & - & 0.0 \\
\hline 7 & Potatoes peel & 1 & 2 & - & 1 & - & 1.0 \\
\hline \multirow[t]{2}{*}{8} & Potatoes vine & - & - & - & - & 1 & 0.0 \\
\hline & Fruits crop residues & & & & & & \\
\hline 9 & Banana peel & 2 & - & 1 & 2 & - & 1.0 \\
\hline 10 & Plantain peel & 2 & - & 2 & 2 & 2 & 2.0 \\
\hline \multirow[t]{2}{*}{11} & Orange peel & 1 & 3 & 2 & 1 & 2 & 2.0 \\
\hline & Leguminous crop residues & & & & & & \\
\hline 12 & Groundnut haulms & - & - & - & - & 1 & 0.0 \\
\hline 13 & Cowpea haulms & - & - & - & - & 1 & 0.0 \\
\hline \multirow[t]{2}{*}{14} & Soyabean haulms & 2 & 1 & 1 & 1 & 1 & 1.0 \\
\hline & Agro-industrial by- products & & & & & & \\
\hline 15 & Groundnut cake & 3 & 3 & 2 & 1 & - & 2.0 \\
\hline 16 & Cotton seed cake & - & - & - & - & 1 & 0.0 \\
\hline 17 & Beniseed cake & 1 & 1 & - & - & 1 & 1.0 \\
\hline 18 & Castor seed cake & 2 & - & 1 & 1 & - & 1.0 \\
\hline 19 & Palm kernel cake & 2 & - & 2 & 2 & - & 1.0 \\
\hline 20 & Brewers dry grain & - & 3 & 2 & 2 & - & 1.0 \\
\hline 21 & Molasses & 1 & - & 1 & 1 & - & 1.0 \\
\hline 22 & Brewers spent grain & 1 & - & 1 & - & - & 0.0 \\
\hline 23 & Rice bran & 2 & 1 & 2 & 2 & 1 & 2.0 \\
\hline 24 & Maize offal & 2 & 3 & 2 & 3 & 1 & 2.0 \\
\hline 25 & Wheat bran & - & - & - & - & 1 & 0.0 \\
\hline Key: & $\begin{array}{l}1=\text { Scarce } \\
2=\text { moderately available } \\
3=\text { easily available }\end{array}$ & & & & & & \\
\hline
\end{tabular}

Table 5: Mean score of frequency of collection of crop residues and agro-industrial byproducts in five communities in Makurdi L. G. A (To the nearest whole number)

\begin{tabular}{|c|c|c|c|c|c|c|}
\hline \multirow[b]{2}{*}{ Farmer/respondent } & \multicolumn{6}{|c|}{ Mean score of frequency of collection } \\
\hline & Akile & Yaikyo & Wurukum & Agan & Adaka & mean \\
\hline 1 & 1 & 1 & 2 & 2 & 2 & 2 \\
\hline 2 & 3 & 1 & 2 & 2 & 2 & 2 \\
\hline 3 & 2 & 2 & 1 & 2 & 3 & 2 \\
\hline 4 & 1 & 2 & 1 & 2 & 4 & 2 \\
\hline 5 & 2 & 3 & 2 & 4 & 2 & 3 \\
\hline 6 & 2 & 2 & 2 & 1 & 2 & 2 \\
\hline 7 & 4 & 2 & 4 & 2 & 4 & 3 \\
\hline 8 & 4 & 4 & 4 & 1 & 3 & 3 \\
\hline Mean & 2.4 & 2.3 & 2.4 & 2 & 2.8 & 2.4 \\
\hline
\end{tabular}

Key: score frequency of collection
once daily
twice daily
thrice daily
more than three times/day 
Traditional Sheep and Goat Production in Rural Communities of Markudi LGA

Table 6: Mean score of distance from source of crop residues and agro-industrial by-products collection in five communities of Makurdi L. G.A (To the nearest whole numbers).

\begin{tabular}{ccccccc}
\hline Farmers/respondents & Akile & Yaikyo & Wurukum & Agan & Adaka & Mean \\
\hline 1 & 3 & 4 & 1 & 3 & 4 & 3 \\
2 & 4 & 4 & 4 & 3 & 3 & 4 \\
3 & 3 & 4 & 4 & 4 & 3 & 4 \\
4 & 4 & 4 & 3 & 3 & 4 & 4 \\
5 & 3 & 4 & 4 & 3 & 4 & 3 \\
6 & 4 & 3 & 3 & 4 & 3 & 4 \\
7 & 4 & 2 & 3 & 4 & 3 & 3.6 \\
8 & 4 & 4 & 4 & 3.5 & 3.4 & \\
\hline
\end{tabular}

Key: score Distance from source of crop residues

$\begin{array}{cll}1 & \text { very far } & \text { over } 1 \mathrm{~km} \\ 2 & \text { far away } & 800 \mathrm{~m}-1 \mathrm{~km} \\ 3 & \text { close } & 400 \mathrm{~m}-800 \mathrm{~m} \\ 4 & \text { very close } & \text { less than } 400 \mathrm{~m}\end{array}$

Table 7: Time (seasonality) of availability of crop residues and agro-industrial byproducts in Markurdi local government area.

\begin{tabular}{|c|c|c|}
\hline $\mathrm{S} / \mathrm{N}$ & Residues & Months ${ }^{*}$ \\
\hline \multicolumn{3}{|c|}{ Cereal crop residues } \\
\hline 1 & Millet stover & $4-9$ \\
\hline 2 & Rice busk & $1-12$ \\
\hline 3 & Rice straw & $1-12$ \\
\hline \multicolumn{3}{|c|}{ Root crop residues } \\
\hline 4 & Yam peel & $1-12$ \\
\hline 5 & Cassava peel & $1-12$ \\
\hline 6 & Cocoyam peel & $1-12$ \\
\hline 7 & Potatoes peel & $1-12$ \\
\hline 8 & Potatoes vine & $1-12$ \\
\hline \multicolumn{3}{|c|}{ Fruits crop residue } \\
\hline 9 & Banana peel & $11-2$ \\
\hline 10 & Plantain peel & $11-2$ \\
\hline 11 & Orange peel & $11-2$ \\
\hline \multicolumn{3}{|c|}{ Leguminous crop residues } \\
\hline 12 & Groundnut haulms & $4-11$ \\
\hline 13 & Cowpea haulms & $1-8$ \\
\hline 14 & Soyabean haulms & $1-12$ \\
\hline \multicolumn{3}{|c|}{ Agro industrial by products } \\
\hline 15 & Groundnut cake & $1-12$ \\
\hline 16 & Cotton seed cake & $1-12$ \\
\hline 17 & Beniseed cake & $4-9$ \\
\hline 18 & Castor seed cake & $9-10$ \\
\hline 19 & Palm kernel cake & $1-12$ \\
\hline 20 & Brewer dry grain & $1-12$ \\
\hline 21 & Molasses & $1-12$ \\
\hline 22 & Brewers spent grain & $4-8$ \\
\hline 23 & Rice bran & $1-12$ \\
\hline 24 & Maize offal & $1-12$ \\
\hline 25 & Wheat bran & $9-1$ \\
\hline
\end{tabular}


Onyeonagu, C.C. and Njoku, O.L.

Table 9 summarized the problems encountered by livestock farmers in crop residue collection in the area. Bulkiness of material and bad road in the area of collection featured prominently. Other problems included high cost of transportation, termite infestation, high purchasing cost, lack of good storage and preservation, fire incidence and inclement weather.

The alkaloid contents of the crop residues varied significantly among the crop residues and agro-industrial by-products with molasses giving the highest alkaloid content compared with soybean husk, brewers spent grain, cassava peel, groundnut cake, maize offal, rice bran, but were similar to yam peel (Table 10). Phytate contents of the crop residues varied significantly among the crop residues with molasses having the highest phytate content compared with brewers spent grain, cassava peel, groundnut cake, maize offal, rice bran, soybean husk and yam peel. Saponin contents of the crop residues varied significantly among the crop residues with brewers spent grain giving the highest percentage of saponin compared with cassava peel, groundnut cake, molasses, maize offal, rice bran, soybean husk, yam peel but was similar with rice husk. Tannin contents varied significantly among the crop residues with cassava peel giving the highest percentage of tannin compared with molasses, maize offal, rice bran, soybean husk, yam peel, rice husk but was similar with brewers spent grain and groundnut cake.

Table 8: Perceived animal acceptability rating of identified crop residues and agroindustrial by-products in Makurdi local government area.

\begin{tabular}{|c|c|c|}
\hline S/No & Residues & Perceived acceptability rating (scales 1-4) \\
\hline & Cereal residues & \\
\hline 1 & Millet stover & 2 \\
\hline 2 & Rice busk & 4 \\
\hline \multirow[t]{3}{*}{3} & Rice straw & 4 \\
\hline & Mean & 3 \\
\hline & Root residues & \\
\hline 4 & Yam peel & 4 \\
\hline 5 & Cassava peel & 4 \\
\hline 6 & Cocoyam peel & 2 \\
\hline 7 & Potatoes peel & 3 \\
\hline \multirow[t]{3}{*}{8} & Potatoes vine & 3 \\
\hline & Mean & 3 \\
\hline & Fruits residue & \\
\hline 9 & Banana peel & 2 \\
\hline 10 & Plantain peel & 2 \\
\hline \multirow[t]{3}{*}{11} & Orange peel & 2 \\
\hline & Mean & 2 \\
\hline & Leguminous residues & \\
\hline 12 & Groundnut haulms & 3 \\
\hline 13 & Cowpea haulms & 1 \\
\hline \multirow[t]{3}{*}{14} & Soyabean haulms & 2 \\
\hline & Mean & 2 \\
\hline & Agro industrial by products & \\
\hline 15 & Groundnut cake & 4 \\
\hline 16 & Cotton seed cake & 2 \\
\hline 17 & Beniseed cake & 2 \\
\hline 18 & Castor seed cake & 2 \\
\hline 19 & Palm kernel cake & 4 \\
\hline 20 & Brewer dry grain & 3 \\
\hline 21 & Molasses & 3 \\
\hline 22 & Brewers spent grain & 3 \\
\hline 23 & Rice bran & 4 \\
\hline 24 & Maize offal & 4 \\
\hline \multirow[t]{2}{*}{25} & Wheat bran & 1 \\
\hline & Mean & 3 \\
\hline Key: scale & Acceptability rating & \\
\hline 1 & little & \\
\hline 2 & average & \\
\hline 3 & good & \\
\hline 4 & very good & \\
\hline
\end{tabular}


Table 9: Problems encounted by livestock farmers in collection of crop residues and agro-industrial by-products in Makurdi local government area.

\begin{tabular}{|c|c|c|c|c|c|c|}
\hline \multirow[b]{2}{*}{ S/N. Problems } & \multicolumn{6}{|c|}{ Percentages of respondents } \\
\hline & Akile & Yaikyo & Wurukum & Agan & Adaka & means \\
\hline 1. Bulkiness of materials & 15 & 15 & 12.5 & 10 & 15 & 13.5 \\
\hline 2. High cost of transportation & 20 & 10 & 7.5 & 10 & 15 & 12.5 \\
\hline 3. Bad roads & 15 & 15 & 10 & 15 & 10 & 13.0 \\
\hline $\begin{array}{l}\text { 4. Lack of good means of } \\
\text { storage and preservation }\end{array}$ & 17.5 & 7.5 & - & 2.5 & 12.5 & 8 \\
\hline 5. Fire incidence & 5 & - & 10 & 7.5 & 7.5 & 6 \\
\hline 6. Termite infestation & 12.5 & 7.5 & 7.5 & 7.5 & 10 & 9 \\
\hline High purchasing cost & 7.5 & 7.5 & 5 & 12.5 & 7.5 & 8 \\
\hline 8. Inclement weather & 25 & - & 5 & 12.5 & 7.5 & 5.5 \\
\hline
\end{tabular}

Table 10: Anti-nutrient component of some crop residues and agro-industrial byproducts (\%) found in Makurdi local government area.

\begin{tabular}{|c|c|c|c|c|}
\hline Residue & alkaloid & phytate & saponin & tannin \\
\hline Brewers spent grain & 0.0023 & 0.0180 & 5.1803 & 1.953 \\
\hline Cassava peel & 0.0027 & 0.0333 & 1.0503 & 2.219 \\
\hline Groundnut cake & 0.0030 & 0.0130 & 3.3697 & 2.178 \\
\hline Molasses & 0.0053 & 0.0840 & 4.9427 & 0.096 \\
\hline Maize offal & 0.0023 & 0.0103 & 4.4107 & 1.065 \\
\hline Rice bran & 0.0027 & 0.0117 & 3.5077 & 1.427 \\
\hline Rice husk & 0.0027 & 0.0283 & 5.1593 & 1.317 \\
\hline Soybean husk & 0.0020 & 0.0177 & 3.8403 & 1.672 \\
\hline Yam peel & 0.0040 & 0.0127 & 3.9493 & 1.823 \\
\hline s.e.d. between 2 residue means & 0.0007 & 0.0170 & 0.0307 & 0.1587 \\
\hline
\end{tabular}

\section{DISCUSSION}

The mean animal number per farmer in this study which was 14 for goats and 10.2 for sheep was higher than the result of Edokwe (1991), Orok and Duguma (1987) and Onyeonagu and Asiegbu (2008) who reported 10 goats and 9 sheep in the old Anambra, 11 goats and 9 sheep in the old cross river state and 5 goats and 1 sheep in Nsukka, respectively. The 14 crop residues identified in Makurdi in this study compared favourably to the value by Ayoola and Ayoade (1991) who reported fifteen crop residues in the northern part of Nigeria. This study provides livestock managers and feed production experts in the area an in depth information on crop residues in the area. As a result of the proximity of the source of the collection of residues, most farmers feed their livestock twice daily to satisfy the increasing feed requirement of the ruminants. All Year round (all season) availability of crop residues and agro-industrial by-products obtained in this study agrees with the report of Ayoola and Ayoade (1991). Bulkiness of materials and bad roads ranked high among the problems of crop residue utilization in the area. Ayoola and Ayoade (1991) noted that farmers prefer natural pasture because of the problem of bulkiness of crop residues materials and the problem of bad roads in Nigeria.

The tannin contents of most crop residues considered are lower than $2 \%$ reported in sorghum grains (Price and Butter, 1997) with the exception of cassava peel and groundnut cake. In sheep and cattle, dietary tannin levels of 2 and 5\%, respectively, have been reported to have adverse effects on digestibility (Meleod, 1974). Most of the crop residues are below this level of toxicity. Phytate level of crop residues and agro-industrial by-products were considerably lower than those reported by Rachel (1979). These levels are unlikely to have any adverse consequence in ruminants although they could be of dietary importance to monogastric animals since they lack the phytase needed to break down the phytin to release phosphorus. Alkaloid levels of crop residues were considerably lower than those reported by (Berley, 1969). Tilley and Terry (1963) reported that most crop residues contain saponin. However, the quantities of saponin produced by the crop residues and agro-industrial by-products are too low to pose major animal health problems (Tilley and Terry, 1963).

\section{CONCLUSION/RECOMMENDATION}

The present study reveals the possibility of integrating crop residues and agro-industrial by-products in livestock production enterprise. Fourteen crop residues and 11 agro-industrial by-products were identified. Most of the crop residues are available and utilized all the year round. The crop residues and agro-industrial byproducts have low levels of anti nutrients and are therefore recommended for livestock feeding. 
Onyeonagu, C.C. and Njoku, O.L.

\section{REFERENCE}

Adegbola, A.A. and Omele, T.A. (1973). A simple technique for preparing discarded cocoa-bean meal for use in livestock feed. Nig. Agric. Journal 10 (1): $72-81$.

Agarwal, I.S. and Verma, M.L. (1983). Experiences in on-farm research and application of by-product use for animal feeding in Asia. In: By-products utilization for Animal Production. Proc. Workshop on Applied Research, Nairobi, Kenya, 26-30 September 1982. pp 140-147.

Ayoola, G.B. and Ayoade, J.A. (1991). A survey of small holder livestock production in Benue State Nigeria Department of Animal production, University of Agriculture, Makurdi, Nigeria.

Berley, H. (1969). Practical clinical chemistry William Heinmann, London. 431-432.

Edokwe, R.E. (1991). Influence of guinea grass density, undersowing date and $\mathrm{N}$ fertilizer on the performance of guinea grass-maize mixture. B.Sc. Project Report submitted to the faculty of Agriculture University of Nigeria, Nsukka 51p.

Fetuga, B.L and Ogunfowora, O. (1976). The supply and utilization of some major oilseeds and oilseeds cakes in Nigeria. Nig. J. Anim. Prod. 3 (2): 43-52.

Food and Agricultural Organization (1999). World Production of Animal Protein Year book Vol. 20.

Iyegbe-Erakpotobor, G.T., Otchere, E.O., Tegbe, T.S.B., Jegede, J.O. and Abeke, F.O. (2002). A review of some Agroindustrial by-producs in the nutrition of pigs. National Animal Production Research Institute Ahamdu Bello University Shika-Zaria, Nigeria.
Meleod, M..N. (1974): Plant tannis. Their role in forage quality. Nutrition Abstract Review, 44: 803-815.

O'Donovah, P.B. (1979). Fattening cross breed and Zebu cattle on local feed and by products in Ethiopia. A Journal on World animal Review, 30: 23-29

Onyeonagu, C.C. and Asiegbu, J.E. (2008). Estimation of availability and distribution of browse species and number of small ruminant animals among farmers in selected communities of Nsukka Area of Enugu State. Nig. J. Anim. Prod. 35 (2): 252 - 258.

Orok, E.J. and Duguma, B. (1987). Sheep and Goat production in south-eastern Nigeria (Eds. L. Reynolds and A. N. Attah-Krah)Proceedings of Symposium, Owerri, Nigeria. ILCA, Humid zone programme, Ibadan, Nigeria, pp 2-12.

Price, M.L. and Butter, L.G. (1997). Rapid Visual Estimation and spectrophotometric determination of tannin content of sorghum grains. Dept of Biochemistry, Purdue University West Lafayetla, Indiana 47907, Vol 25 No 6, $268 \mathrm{pp}$.

Rachel, V. M. (1979). Western regional research laboratory, Agricultural Research Service U.S. Dept. of Agriculture, Albany, California

Steel, G.D. and Torrie, J.H. (1980). Principles and procedures of statistics, $2^{\text {nd }}$ (ed) Mc Graw Hill book Co. Inc. New York.

Tegbe, T.S.B. (1981). Potential for production of alternative protein sources for swine in Nigeria. Nig. J. Animal Prod 8 (1\& 2): 23.

Tilley, J.M.A. and Terry, R.A. (1963). A two stage technique form vitro digestion of forage. Journal, of the British Grassland Society, 18: $104 \quad-111$ 